\title{
Causes and frequency of conversion during laparoscopic cholecystectomy in own material
}

\author{
Bogdan Kopeć ${ }^{1}$, Ryszard Marciniak² \\ 1Surgery Department, District Hospital, Radziejowo, Poland \\ 2Department of General, Gastrointestinal and Endocrinology Surgery, Medical University of Poznan, Poland
}

Videosurgery and other miniinvasive techniques 2010; 5 (4): 132-138 DOI: 10.5114/wiitm.2010.18824

\begin{abstract}
Aim: To assess the causes, frequency and time of conversion from laparoscopic to classic cholecystectomy in our own material.

Material and methods: 547 patients were qualified for laparoscopic cholecystectomy in the Surgery Department of the Mogilno District Hospital in Strzelno during the period of 1999-2005; 515 minimally invasive operations were performed and 32 patients required conversion.

Results: The 547 patients were qualified for the laparoscopic operation; of these 148 were operated on as emergency cases and 399 as elective cases. There were 20 conversions among emergency patients and 12 conversions among elective patients. On average the decision to convert was made in the $35^{\text {th }}$ min of the operation. The shortest time to conversion was $15 \mathrm{~min}$ and the longest was $90 \mathrm{~min}$. Five conversions were performed in the 25th and $35^{\text {th }} \mathrm{min}$ and 4 in the 20th, 30th, and 40th mine. Most frequently conversions occurred between the 20th and $40^{\text {th }}$ min of the procedure. Intentional conversions were performed in 27 patients. Adhesions and clumps around the gallbladder were the cause of conversion in 10 patients and that was the most frequent reason for the operative modality change. The next cause of conversion was changes observed in the course of acute cholecystitis in the form of gallbladder empyema or cholecystocele (9 patients). Small, fibrotic gallbladder, immersed in the liver, was the reason for conversion in a further 4 patients. In 4 cases the conversion was caused by difficulties in the identification of anatomical structures. Four cases of forced conversions and 1 anticipated conversion were found in the analysed material.

Conclusions: A change of operative modality during laparoscopic cholecystectomy was made on average in 5.85\% of operations. The average time before the conversion was $35 \mathrm{~min}$. Emergency patients required a change of operative modality 4 times more often. The most frequent were intentional conversions (84\%), caused by pericystic adhesions and by inflammatory changes impeding the identification of anatomical structures. The predominant cause of forced conversions was intra-operative haemorrhage.
\end{abstract}

Key words: cholecystectomy, laparoscopic cholecystectomy, conversion

\section{Introduction}

Changing from laparoscopic to classic, open operation is called conversion. Switching the operative approach can be due to various factors and should not be assumed a complication of laparoscopic chole- cystectomy but only a deliberate decision to change the operative technique, frequently protecting the patient from complications [1-6]. Among the causes of conversions one can distinguish:

1. Intentional conversions take place when the operator concludes that the anatomical or pathological 
changes prevent further laparoscopic manipulation. Inflammatory or neoplastic infiltration of the hepato-duodenal ligament and the gallbladder wall may cause serious difficulties in the correct identification of anatomical structures and therefore may increase the risk of damage to bile ducts or other organs.

2. Forced conversions are due to the occurrence of complications (most frequently haemorrhage, bile duct or intestinal tract damage, damage to the vessels of the abdominal wall, diaphragm damage, fistula identification) that the surgeon is not able to deal with using the laparoscopic approach.

3. Anticipated conversions refer to patients qualified for elective laparoscopic cholecystectomy, in whom the data from the anamnesis, general condition or the preoperative laboratory tests suggest presence of additional diseases apart from the well-known cholelithiasis. These could be for instance neoplasms or other disorders of the abdominal cavity masked by the co-existing cholelithiasis $[1,7,8]$.

\section{Aim}

The aim of this study was to assess the causes, frequency and the time of the conversion from laparoscopic to classic cholecystectomy in our own material.

\section{Material and methods}

The 547 patients were qualified for laparoscopic cholecystectomy in the Surgery Department of the Mogilno District Hospital in Strzelno during the period of 1999-2005. Among them 515 laparoscopic operations were completed (Table I). In 32 cases the need for conversion from laparoscopic to classic cholecystectomy arose. Analysis of the data accumulated in the case notes and operative protocols was performed.

\section{Results}

During the evaluation period, a growing linear trend for laparoscopic operations along with a comparable rising trend for conversions was observed (Figure 1). Performed conversions were divided into intentional, forced and anticipated (Table II). Intentional conversions were performed in 27 patients (Table III). Adhesions and pericystic clumps were the cause of conversion in 10 patients and that was the most frequent reason for the change of operative modality. The next cause of conversion was changes observed in the course of acute cholecystitis in the form of gallbladder empyema or cholecystocele; gangrenous changes, extensive inflammatory infiltration of the gallbladder wall, omental clumps to the gallbladder wall, or fragility of the inflamed gallbladder forced the conversion in 9 patients (3 females and 6 males). Small, fibrotic gallbladder, immersed in the liver, was the reason for conversion in a further 4 patients ( 3 females, 1 male). In 4 cases ( 3 females, 1 male) the conversion was caused by difficulties in the identification of anatomical structures.

Four cases of forced conversions occurred in the analysed material: 3 caused by a massive haemorrhage and 1 as a result of the identification of cholecysto-duodenal fistula.

1. A 64-year-old female patient with co-morbid coronary heart disease and arterial hypertension was admitted as an emergency case for operative treatment. The patient was operated on in the first 24 hours from admission. The gallbladder was inflamed, fragile, difficult to grasp with laparoscopic instruments. After providing for the cystic duct and artery and during the gallbladder's liberation with the diathermy hook, difficult to stop haemorrhage from the liver's parenchyma occurred. It was caused by difficulties with preparation of the proper layer. The decision to convert was made in the $40^{\text {th }} \mathrm{min}$ of the operation and the haemorrhage

Table I. Number of performed laparoscopic cholecystectomies and following conversions, during the years 1999-2005

\begin{tabular}{|lcccccccc|}
\hline Operation & \multicolumn{8}{c|}{ Year } \\
\cline { 2 - 10 } & 1999 & 2000 & 2001 & 2002 & 2003 & 2004 & 2005 & Total \\
\hline Laparoscopic & 44 & 82 & 86 & 71 & 78 & 86 & 68 & 515 \\
\hline Conversions & 4 & 2 & 8 & 2 & 2 & 3 & 11 & 32 \\
\hline$\%$ conversions & 8.3 & 2.4 & 8.5 & 2.7 & 2.5 & 3.4 & 13.9 & 5.8 \\
\hline
\end{tabular}




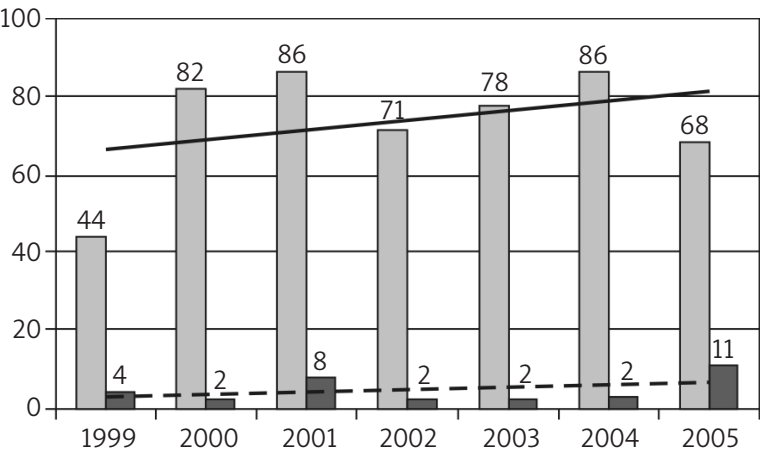

$\square$ laparoscopic

— linear trend of laparoscopic operations

$\square$ conversions

- - linear trend of conversions

Figure 1. Quantitative proportions of laparoscopic procedures and conversions during 1999-2005

was aborted by a continuous stitch applied to the gallbladder bed. The post-operative period was uneventful and the patient did not require blood transfusion.

2. A 69-year-old female patient was admitted as an emergency case and was treated operatively on the admission day. The gallbladder was inflamed and strained in multiple planes by the omental adhesions. During preparation of the structures of Calot's triangle, injury of the trunk of the cystic artery with massive haemorrhage occurred. Immediate laparotomy was performed $\left(40^{\text {th }}\right.$ min of the operation), and after being located, the bleeding vessel was ligated. Two units of packed red cells were transfused.

3. A 28-year-old, previously healthy, male patient was admitted for an elective procedure because of symptomatic cholelithiasis. The patient was treated operatively on the admission day. The thinwalled gallbladder was removed in a typical manner; the cystic duct and artery were closed twice with titanium clips. After the gallbladder's extraction from the peritoneal cavity and closure of the peritoneal defect below the umbilicus, during the drain insertion to the gallbladder bed, a massive haemorrhage was noticed - the conversion was performed in the $65^{\text {th }} \mathrm{min}$ of the procedure. A haemorrhage from the cystic artery stump that was damaged by forceful clip application was found. The bleeding site was treated with a double
Table II. Types of conversions in the analysed material

\begin{tabular}{|lccc|}
\hline Conversion type & Female & Male & Total \\
\hline Intentional conversion & 15 & 12 & 27 \\
\hline Forced conversion & 3 & 1 & 4 \\
\hline Anticipated conversion & 1 & 0 & 1 \\
\hline Total & 19 & 13 & 32 \\
\hline
\end{tabular}

Table III. Causes of intentional conversions

\begin{tabular}{|lccc|}
\hline $\begin{array}{l}\text { Causes of intentional } \\
\text { conversions }\end{array}$ & Female & Male & Total \\
\hline $\begin{array}{l}\text { Adhesions and pericystic } \\
\text { clumps }\end{array}$ & 6 & 4 & 10 \\
\hline $\begin{array}{l}\text { Acute inflammatory changes, } \\
\text { inflammatory infiltration, } \\
\text { empyema or cholecystocele }\end{array}$ & 3 & 6 & 9 \\
\hline Small, fibrotic gallbladder & 3 & 1 & 4 \\
\hline $\begin{array}{l}\text { Difficulties in identification } \\
\text { of anatomical structures }\end{array}$ & 3 & 1 & 4 \\
\hline
\end{tabular}

ligature. Four units of packed red cells were administered during the peri-operative period.

4. Cholecysto-duodenal fistula was diagnosed in a 71-year-old female patient admitted for elective operative treatment. During the operation a small, fibrotic gallbladder adhering to the duodenum was discovered. The attempt to free the gallbladder from the adhesions revealed the presence of the fistula.

Anticipated conversion occurred in the case of a 76-year-old female patient admitted for elective operative treatment of symptomatic cholelithiasis with 3 years history. The patient had the following concomitant disorders: insulin-dependent diabetes mellitus, arterial hypertension, circulatory failure stage 2 according to NYHA (on the basis of atheromatous degeneration of the myocardium). Biochemical and serological tests showed no aberrations. Ultrasound scan revealed a small liver with irregular margin and nodular changes, especially on the diaphragmatic surface, and irregular parenchyma structure with heterogeneous hyperechogenicity. The patient was qualified for the laparoscopic procedure with the provision of possible conversion due to the changes described in the ultrasound scan report sug- 
gesting hepatocirrhosis. During the laparoscopic evaluation, small, dense liver with nodular changes was found. The decision to change the operative method was made in the $15^{\text {th }}$ min following previous assessment of the remaining abdominal cavity organs accessible to the laparoscope. The cholecystectomy was performed and a sectional sample from the liver was taken for histopathology examination. The postoperative period was not complicated, and the patient was discharged home on the fifth post-operative day in good general and local condition. The histopathology examination reports: Cholecystitis chronica purulenta et fibrosans. Cirrhosis portali hepatis cum steatosi.

During all the observation years intentional conversions prevailed and the highest numbers were performed in the years 2001 and 2005. In 2002 only 1 intentional and 1 forced conversion were recorded (Figure 2). Intentional conversions accounted for $84 \%$ of all those performed. Forced and anticipated conversions together comprised $16 \%$ (13\% and 3\% respectively).

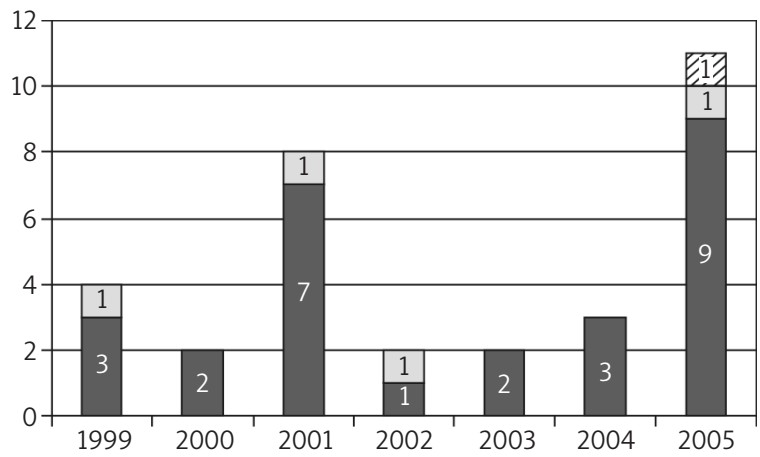

$\square$ international $\square$ forced anticipated

Figure 2. Causes of conversions in the years 1999-2005

Table IV. Conversions among elective and emergency patients

\begin{tabular}{|lcc|}
\hline Type & \multicolumn{2}{c|}{ Urgency } \\
\cline { 2 - 3 } & Emergency $(n=148)$ & Elective $(n=399)$ \\
\hline Intentional [\%] & 12.16 & 2.25 \\
\hline Forced [\%] & 1.35 & 0.5 \\
\hline Anticipated [\%] & - & 0.25 \\
\hline Total [\%] & 13.51 & 3.0 \\
\hline
\end{tabular}

The frequency of conversions in the whole group of patients qualified for laparoscopic cholecystectomy admitted as elective and emergency cases was assessed. 547 patients were qualified for the laparoscopic operation; of those, 148 were operated on as emergency cases and 399 as elective cases. There were 20 conversions among emergency patients and 12 conversions among elective patients. The proportion of conversions depending on admission mode is presented in Table IV.

Figure 3 shows that intentional conversions were performed two times more frequently in emergency cases than elective ones.

The shortest time to conversion was 15 min and the longest was $90 \mathrm{~min}$. On average the decision to convert was made in the $35^{\text {th }}$ minute of the operation. Figure 4 displays the number of conversions in 5-min time intervals. Five conversions were performed in the $25^{\text {th }}$ and $35^{\text {th }}$ min and 4 in the $20^{\text {th }}$, $30^{\text {th }}$, and $40^{\text {th }}$ min. Most frequently conversions

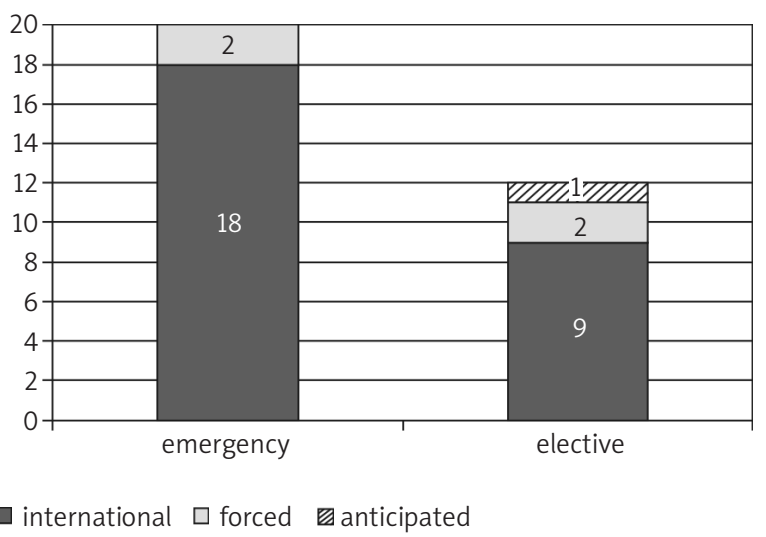

Figure 3. Intentional, forced and anticipated conversions based on the type of admission

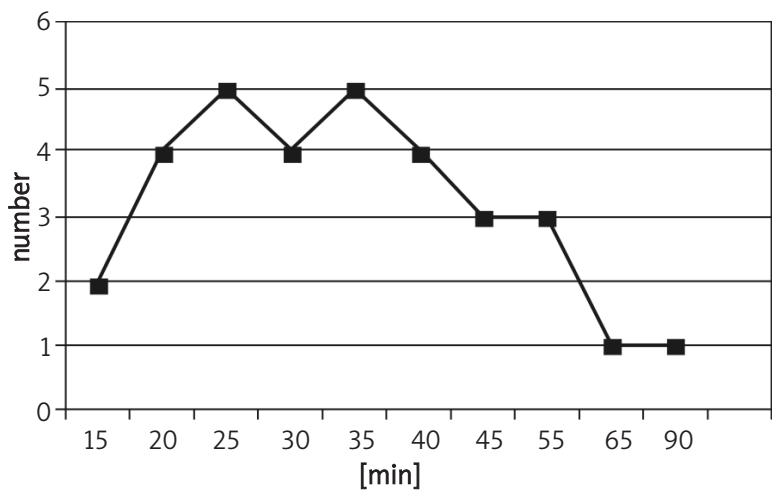

Figure 4. Conversions and time of the procedure 
occurred between the $20^{\text {th }}$ and $40^{\text {th }}$ min of the procedure.

\section{Discussion}

In the analysed material the need for conversion occurred in 32 subjects (19 females and 13 males), which constituted $5.85 \%$ of patients qualified for a laparoscopic procedure. In the literature this proportion is in the range of $2.1-27.7 \%$ [1, 2, 5, 7-14]. A conversion rate not exceeding $5 \%$ for elective cases and not greater than $10 \%$ for emergency cases is recognized as a good standard of surgical practice in British centres [15]. In the opinion of some authors, conversions take place twice as often during procedures in males $[2,13,16,17]$. In our material that view was not confirmed - males constituted $40 \%$ of subjects requiring a conversion. Similar results were shown by Golebiowski - males constituted $41.1 \%$ of patients subjected to conversion among 111 described [19]. According to Stanowski conversions can be divided into intentional, forced and anticipated [1]. In the literature a division into planned and forced conversions can be found as well [12]. In this publication the first classification was used, assuming that it better reflects the indications for conversion and that the term 'planned' contradicts the idea of conversion. It is difficult to assume the need for conversion prior to the operation. It is the operation's dynamics that force a decision to change the operative technique. The patient should be qualified for the open procedure if the clinical assessments before the operation and laboratory tests' results anticipate high probability of conversion. Many authors think that the preoperative symptoms should decide on the operative technique, and the expectation of con- version imposes a requirement to operate with the classic technique [5-7, 18, 23].

In the presented material, most of the conversions were intentional. They accounted for $84 \%$ of all performed conversions. The reasons for conversions in this group most frequently were adhesions and pericystic clumps (32\%) and acute inflammatory changes in the form of extensive inflammatory infiltration, cholecystocele or empyema of the gallbladder (28\%). Less frequently intentional conversion was performed because of small, fibrotic and difficult to liberate gallbladder or due to difficulties in the identification of anatomical structures (12.5\% each).

Forced conversions accounted for $13 \%$ of all performed conversions. In 3 cases intense haemorrhage (10\%) and in 1 patient a diagnosed cholecysto-duodenal fistula (3\%) was the indication for conversion. The indication for the single anticipated conversion was co-existing hepatocirrhosis (3\%).

In the study by Stanowski et al. evaluating 6873 laparoscopic cholecystectomies the authors describe 111 conversions (1.615\%) (Table V). In the study there was a majority of intentional conversions (61.26\%) due to difficulties with the identification of anatomical structures, inflammatory infiltration of the Calot's triangle area preventing safe preparation (14.41\%), and adhesions in the area of the gallbladder (9.9\%) and other regions of the abdominal cavity following previous surgery (14.41\%). In the study by Stanowski et al., the most frequent cause of forced conversions was haemorrhage caused by injury of the large vessels $(32.43 \%)$ or intra-operative, impossible to limit laparoscopically (9\%). The cause of anticipated conversions was disseminated neoplastic process coexistent with cholelithiasis (1.8\%) and acute abdominal disorders masked by cholelithiasis (4.5\%) [1]. In the

Table V. Causes of conversions in the literature $[3,4,11,15,19]$

\begin{tabular}{|lcccccc|}
\hline Cause of conversion & \multicolumn{5}{c|}{ Author } \\
\cline { 2 - 7 } & Stanowski & Skonieczny & Kok-Ren Lim & Bingener-Casey & Kot & Own material \\
\hline $\begin{array}{l}\text { Difficulties in identification } \\
\text { of anatomical structures }\end{array}$ & 61.26 & 13.6 & 46.4 & 50.0 & 80.0 & 12.5 \\
\hline Inflammatory infiltration & 14.41 & - & - & - & - & 28.0 \\
\hline Pericystic clumps & 9.9 & 61.36 & 35.5 & - & - & 32.0 \\
\hline Haemorrhage & 32.43 & 6.25 & 17.0 & 14.0 & 16.7 & 9.0 \\
\hline Bile duct damage & - & - & - & 8.0 & - & - \\
\hline
\end{tabular}


study by Skonieczny et al., among 1804 laparoscopically treated cases, conversions were performed in $9.6 \%$ of procedures. The main indications for conversion were adhesions (61.36\%), technical difficulties e.g. difficulties with cystic duct clipping (15.9\%), difficulties with identification of anatomical structures (13.6\%), haemorrhage $(6.25 \%)$, gallbladder perforation (4.5\%) and laparoscopic equipment failure (2.27\%) [2]. In a work from the Republic of Singapore based on the evaluation of 145 procedures the conversion rate was $27.7 \%$, and the most frequent causes were difficulties in the identification of anatomical structures (46.4\%), haemorrhage (17\%) and adhesions in the area of the gallbladder (35.8\%) [10]. In the study by Bingener-Casey et al., among 5884 patients operated on laparoscopically, the authors present 310 conversions (5.2\%), mostly due to difficulties in identification of anatomical structures (50\%), haemorrhage (14\%), bile duct injury ( $8 \%)$, suspicion of choledocholithiasis (11\%) and others (16\%) [11]. In the work by Kot et al., among 1411 laparoscopic procedures $4.25 \%$ of conversions were noted. The authors name as the causes unclear anatomical relations (80\%) and haemorrhage (16.7\%) as well as single cases in which rupture of the gallbladder with multiple gallstones spread and sudden increase of the $\mathrm{CO}_{2}$ pressure in the blood were indications [9].

Predominant causes of conversion are difficulties with identification of anatomical structures (13.6-80\%), pericystic adhesions (9.9-61.36\%), inflammatory infiltration (14.41-72\%) and intra-operative haemorrhage (0.3-32.43\%) [1, 2, 5, 7, 9-13, 19]. Comparing the most frequent causes and their occurrence rates one should conclude that our own observations do not diverge from the other investigators' results. Analysing the available literature, few descriptions of injuries of the main bile duct were noted. There was no such injury in the study that constituted the indication for conversion. In the material of Bingener-Casey et al. bile duct injuries accounted for $8 \%$ of indications for conversion [11]. In the study by Gołębiowski et al. $0.116 \%$ of bile duct injuries were noted during the laparoscopic procedures. Remaining injuries were discovered in the distant post-operative days [19].

In our own study the occurrence of conversions according to the admission type was evaluated. Among patients admitted and operated on as emergencies, conversions occurred in $13.51 \%$. However, only $3 \%$ of patients treated as elective cases required a change of operative modality. Intense inflammato- ry changes of the gallbladder such as cholecystocele or empyema of the gallbladder as well as inflamed adhesions and pericystic clumps significantly impede the procedure. Such changes, more often seen in patients treated as emergencies, explain the over fourfold greater rate of conversions in this group. A similar observation can be made concerning data from the literature [1-3, 5, 7, 9-11, 13].

Of essential importance in 'difficult' laparoscopic operations is the moment of making the decision on conversion. In the analysed material the decision to change from the laparoscopic to the open method was made in the $35^{\text {th }}$ min on average. The timing agrees with other surgeons' recommendations on the necessity to change the operative technique in case of a lack of progress within 30-40 min. Prolongation of the operative time is unnecessary and often involves a higher intra-operative complication rate [20]. There is a univocal position in the literature that a conversion should not be considered a complication of the laparoscopic procedure. Conversion should be considered as a sensible and deliberate decision of the operator $[1,2,5,19,20]$. One should be aware that not all complications force a conversion, since most of them can be eliminated laparoscopically. Delaying or withholding the conversion in so-called "difficult laparoscopies" is dangerous and can be a manifestation of excessive bravery of the surgeon, unfounded ambition or a lack of occupational humility. Adequately early performed intentional conversion reduces the risk of serious intra- and post-operative complications $[1,5,20]$.

\section{Conclusions}

A change of the operative modality during laparoscopic cholecystectomy was performed on average in $5.85 \%$ of operations. The average time before the conversion was 35 min.

Emergency patients required a change of the operative modality 4 times more often. The most frequent were intentional conversions (84\%), caused by pericystic adhesions and by inflammatory changes impeding the identification of anatomical structures. The predominant cause of forced conversions was intra-operative haemorrhage.

\section{References}

1. Stanowski E, Paczyński A, Gołębiowski G, et al. Konwersje w cholecystektomii laparoskopowej. Pol Przeg Chir 2002; 74: 869-74. 
2. Skonieczny B, Pytka M, Stefaniak T, et al. Przyczyny i częstość konwersji podczas zabiegu cholecystektomii laparoskopowej. Pol Przeg Chir 2008; 80: 110-21.

3. Kaafarani HM, Smith TS, Neumayer L, et al. Trends, outcomes, and predictors of open and conversion to open cholecystectomy in Veterans Health Administration hospitals. Am J Surg 2010; 200: 32-40.

4. Gabriel R, Kumar S, Shrestha A. Evaluation of predictive factors for conversion of laparoscopic cholecystectomy. Kathmandu Univ Med J (KUMJ) 2009; 7: 26-30.

5. Ballal M, David G, Willmott S, et al. Conversion after laparoscopic cholecystectomy in England. Surg Endosc 2009; 23: 2338-44.

6. Visser BC, Parks RW, Garden OJ. Open cholecystectomy in the laparoendoscopic era. Am J Surg 2008; 195: 108-14.

7. Kopeć B. Wyniki leczenia i jakość życia pacjentów operowanych z powodu objawowej kamicy pęcherzyka żółciowego w warunkach szpitala powiatowego. (Ph.D. thesis). Poznań 2008.

8. Jarczyk G, Jackowski M, Marcinkowski P. Zmiana profilu leczenia kamicy żółciowej w klinice chirurgii. Analiza dwóch okresów 5-letnich. Pol Przeg Chir 2006; 78: 583-96.

9. Kot M, Głuszek S, Matykiewicz J, et al. Cholecystektomia laparoskopowa - czy jest to bezpieczna metoda operacyjna? Doświadczenia własne. Wideochirurgia 2006; 3: 113-20.

10. Kok-Ren Lim, Salleh I, Ngain-Chye T, et al. Risk factors for conversion to open surgery in patients with acute cholecystitis undergoing interval laparoscopic cholecystectomy. An Ac of Med 2007; 36: 631-5.

11. Bingener-Casey J, Richards ML, Strodel WE, et al. Reason for conversion from laparoscopic to open cholecystectomy: a 10-year review. J Gastrointest Surg 2002; 6: 800-5.

12. Wirkowski A, Pesta W. Pułapki cholecystektomii laparoskopowej - doświadczenia własne. Wideochirurgia i inne techniki małoinwazyjne 2008; 3: 179-85.

13. Rosenmüller M, Haapamäki MM, Nordin P, et al. Cholecystectomy in Sweden 2000-2003: a nationwide study on procedures, patient characteristics, and mortality. BMC Gastroenterol 2007; 7: 35 .

14. Teckchandani N, Garg PK, Hadke NS, et al. Predictive factors for successful early laparoscopic cholecystectomy in acute cholecystitis: A prospective study. Int J Surg 2010 Jul 30 [E-pub].

15. David GG, Al-Sarira AA, Willmott S, et al. Management of acute gallbladder disease in England. Br J Surg 2008; 95: 472-6.

16. Yol S, Kartal A, Vatansev C, et al. Sex as a factor in conversion from laparoscopic cholecystectomy to open surgery. JSLS 2006; 10: 359-63.

17. Thesbjerg SE, Harboe KM, Bardram L, et al. Sex differences in laparoscopic cholecystectomy. Surg Endosc 2010 May 7 [E-pub].

18. Ghnnam W, Malek J, Shebl E et al. Rate of conversion and complications of laparoscopic cholecystectomy in a tertiary care center in Saudi Arabia. Ann Saudi Med 2010; 30: 145-8.

19. Gołębiowski G. Konwersje w cholecystektomii laparoskopowej. (Ph.D. thesis). Warszawa 2002.

20. Bierca J, Kowalski B, Kosim A, et al. Powikłania cholecystektomii laparoskopowej wymagające ponownej interwencji chirurgicznej; analiza 1767 operacji. Wideochirurgia i inne techniki małoinwazyjne 2005; 1: 69. 